\title{
Celebrating the Last 10 Years of Community College Internationalization
}

\author{
Rosalind Latiner Raby \\ California State University, Northridge, USA
}

In the United States, about $36 \%$ of all community colleges offer international student programs, of which, about $13 \%$ also offer education abroad programs (Malveaux \& Raby, 2019). Documentation on community college international education has existed since the 1950s. Advocacy for community college international education is also not new and is found in numerous American Association of Community Colleges publications, association reports, and addresses given by multiple generations of community college leaders who view internationalization as an important way to serve the community college missions of open access, to support gainful employment goals, and to support student success initiatives (American Association of Community Colleges, 2018; Boggs \& Irwin, 2007; Gleazer, 1975). In celebration of the Journal of International Students 10th year anniversary, this essay outlines the advances made in community college mobility programs over the past decade. Mobility here refers to both inbound (international student programs) and outbound (education abroad programs).

Community colleges play a critical role in training adults to gain skills needed for participation in a global economy where required job skills change rapidly. This global economy is a context in which international and cross-cultural skills are in high demand. This demand is being addressed by community colleges adding international learning in their academic and in career training curricula and programs. It is also addressed by fostering access to international programs and activities for all students. In 1996, Raby and Tarrow discussed how "with the current recession, the fate of international education is in jeopardy" (p. 20). In 2012, another recession became the backdrop against severe budget cuts that severely impacted periphery programs such as international education (Raby, 2012). Today, the economic context of COVID will once again redefine the number of students who can afford to travel, the ease of travel, and how much infrastructure support will be given by institutions to support international programs. Yet, in learning from the past, it is evident that 
...when the global economy stabilized so did internationalization efforts. Even more importantly is that after each crisis period, a new generation of individuals emerged as international advocates and who continually seek to implement changes in the college. Herein lays the promise of the future. (Raby, 2019, p. 16)

The promise of the future rests on research previously conducted on community college internationalization as this research embeds advocacy and best practices so that patterns that work do not need to be reinvented. The community college mission does not have a singular focus as it was designed to serve multiple purposes. Internationalization is one of these missions (Ayers, 2015; Gleazer, 1975; Raby, 2019). This works in harmony with a local mandate to prepare graduates to gain local jobs, even those jobs that are located outside the geographic boundary of the college (Ayers, 2015). Internationalization is included in missions (Whatley \& Raby, 2020) and in strategic planning policies (Copeland, 2016).

Open access is a guiding principle that allows enrollment opportunities for all who want to learn. Open access supports current equity agendas. However, equity in international education while encouraging wide-spread enrollment also has limitations. For international students, there are minimum qualifications, including international testing scores and English language proficiencies. Other limitations occur when international students are labeled as a privileged group, which skews the services that they receive (Viggiano et al., 2017). For education abroad, minimum qualifications include grade point average requirements, code of conduct, financial ability, and deficit narratives that stereotype non-traditional students (Whatley \& Raby, 2020).

Today, there are dedicated offices and dedicated mid- and senior-level leadership positions that oversee internationalization. This includes partnerships with senior administration (Brennen \& Dellow, 2013), with academic departments and campus services (Smith, 2019), and with campus assessment practices (Wood, 2019). There are also known areas for augmentation of support services. For international students, this includes office policies (Lau et al., 2019), student advising practices (Zhang, 2016), addressing marginalization resulting from prejudice and discrimination (Hansen et al., 2018), and understanding the heterogeneity of international students (Bennani, 2018). For education abroad, this includes creative financing (Giammarella, 2012), addressing deficit student labels (Raby, 2019; Robertson, 2019; Whatley, 2019), re-examining entry requirements, including planning time (Amani \& Kim, 2017), and understanding when curriculum limits and when it expands free time (McKee, 2019).

Decreased state and federal funding for community colleges complicates the financing of international education offices and accentuates marketing to increase the number of students who enroll in programs, which in turn, directly impacts the larger college budget. Research explains why the college needs to recruit international students (Bohman, 2014), why students want to study in community colleges (Zhang $\&$ Hagedorn, 2013), and why myths can negatively impact student success (Budd et al., 2016; Viggiano et al., 2018). 
Research also shows that international programs positively influence student success that lead to increased persistence, transfer, and completion. This is true for students who study abroad (Raby et al., 2014; Whatley, 2019) and for international students (Benneni, 2018; Slantcheva-Durst \& Knaggs, 2017) whose high academic aspirations help them to overcoming personal challenges (Friedman, 2018).

Since the 1980s, national associations, practitioners, and researchers used advocacy and research to develop and implement best practices. As a result, community college student mobility programs expanded in number and in scope. Today, it is common for colleges to include "international" or "global" in their mission, vision, and annual priorities. There is an increase in full-time dedicated positions for those leading international education, increased access for students to participate in various international programs, expanded use of technologies that further broaden access, and collaborations that extend beyond the campus. Most importantly, students choose to attend community colleges to better themselves, and they make sound decisions to engage in college programs to expand their knowledge, which includes international mobility programs.

In the post-COVID period, it is likely that severe state funding challenges, lower overall and international student enrollments, and high turnover of senior administrators will once again challenge community college international education. I propose that the significant research about community college internationalization has taught five points that will be important drivers in moving international education forward. First, advocacy needs to reinforce that local is not the opposite of global and that international education is indeed one of the community colleges' missions as it encapsulates an academic shift that promotes international literacy as a critical employability and educational skill. Second, avoid haphazard implementation of services that reinforce hegemonic patterns in which some students are given access to life-altering experiences while others are denied those experiences. Third, eliminate student stereotypes that feed into a negative narrative. Fourth, use caution when designating students as a desirable source of revenue. Finally, understand that the limits of student success are connected to a lack of supportive institutional practices rather than to a lack of student interest. Above all, "Change is a choice needed to be made by visionary leaders who must prioritize and then lead these reform efforts that are sustainable and not impacted by the shifting of time and institutional circumstances (Raby, 2019, p. 17).

\section{REFERENCES}

Amani, M., \& Kim, M. M. (2017). Study abroad participation at community colleges: Students' decision and influential factors. Community College Journal of Research and Practice, 41(10), 1-15. doi:10.1080/10668926.2017.1352544

American Association of Community Colleges. (2018). AACC competencies for community college leaders. https:/www.aacc.nche.edu/wpcontent/uploads/2018/11/AACC-2018-Competencies_111618_5.1.pdf

Ayers, D. F. (2015). Credentialing structures, pedagogies, practices, and curriculum goals: Trajectories of change in community college mission statements. Community College Review, 43, 191-214. doi:10.1177/0091552115569847 
Bennani, W. C. (2018). Contributors to the successful transfer of international community college students [Unpublished dissertation]. San Francisco State University, California.

Boggs, G. R., \& Irwin, J. (2007). What every community college leader needs to know: Building leadership for international education. New Directions for Community Colleges, 138, 25-30.

Bohman, E. (2014). Attracting the world: Institutional initiatives' effects on international students' decision to enroll. Community College Journal of Research and Practice, 38(8), 710-720. doi:10.1080/10668926.2014.897081

Brennan, M., \& Dellow, D. A. (2013). International students as a resource for achieving comprehensive internationalization. New Directions for Community Colleges, 161, 27-37.

Budd, D., Serban, A., Van Hook, D. G., \& Raby, R. L. (2016). Addressing myths about international students. In R. L. Raby \& E. J. Valeau (Eds.), International education at community colleges (pp. 215-222). Palgrave McMillan.

Copeland, J. M. (2016). Community colleges' internationalization: Development of an assessment instrument [Unpublished dissertation]. Barry University, Florida.

Friedman, J. Z. (2018). A horse of a different color? Re-examining international students at community colleges in the U.S. and Canada. In R. L. Raby \& E. J. Valeau (Eds.), Handbook on comparative issues of community colleges and global counterparts. Springer.

Giammarella, M. (2012). Using student fees to support education abroad. In S. E. Sutin, D. Derrico, R. L. Raby, \& E. J. Valeau (Eds.), Increasing effectiveness of the community college financial model: A global perspective for the global economy. Palgrave Macmillan.

Gleazer, E. J., Jr. (1975, March 24). Memorandum to community college presidents. American Association of Community and Junior Colleges Newsletter.

Hansen, H. R., Shneyderman, Y., McNamara, G. S., \& Grace, L. (2018). Acculturative stress and native and U.S. culture immersion of international students at a community college. Journal of International Students, 8(1), 215232. https://doi.org/10.32674/jis.v8i1.161

Lau, J., Garza, T., \& Garcia, H. (2019). International students in community colleges: On-campus services used and its effect on sense of belonging. Community College Journal of Research and Practice, 43(2), 109-121.

Malveaux, G. F., \& Raby, R. L. (2019). Study abroad opportunities for community college students and strategies for global learning. IGI-Global.

McKee, A.-M. (2019). A case study exploring ways to increase access to education abroad for career and technical students with limited availability. In G. F. Malvaeux \& R.L. Raby (Eds.), Study abroad opportunities for community college students and strategies for global learning (pp. 242-255). IGI-Global.

Raby, R. L. (2012). Re-imagining international education at community colleges. Audem: International Journal of Higher Education and Democracy, 3, 81-99.

Raby, R. L. (2019). Changing the conversation: Measures that contribute to community college education abroad success. In G. F. Malveaux \& R. L. Raby (Eds.), Study abroad opportunities for community college students and strategies for global learning (pp. 1-22). IGI-Global. 
Raby, R. L., \& Tarrow, N. (Eds). (1996). Dimensions of the community college: International and inter/multicultural perspectives. Garland Publishers.

Raby, R. L., Rhodes, G. M., \& Biscarra, A. (2014). Community college study abroad: Implications for student success. Community College Journal of Research and Practice, 38(2-3), 174-183.

Robertson, J. (2019). The outreach triad for successful study abroad programs: Students, faculty, and the local community. In G. F. Malveaux \& R. L. Raby (Eds.), Study abroad opportunities for community college students and strategies for global learning (pp. 107-120). IGI-Global.

Slantcheva-Durst, S., \& Knaggs, C. (2017). Community college international students and their campus involvement. Community College Journal of Research and Practice, 43(2), 81-93. https://doi.org/10.1080/10668926.2017.1416316

Smith, C. (2019). Institutionalizing international education and embedding education abroad into the campus community. In G. F. Malveaux \& R. L. Raby (Eds.), Study abroad opportunities for community college students and strategies for global learning (pp. 172-184). IGI-Global.

Viggiano, T., López Damián, A. I., Morales Vázquez, E., \& Levin, J. S. (2018). The others: Equitable access, international students, and the community college. Journal of Studies in International Education, 22(1), 71-85.

Whatley, M. (2019). Clearing the hurdle: The relationship between institution-level factors and community college study abroad. In G. Malveaux \& R. L. Raby (Eds.), Study abroad opportunities for community college students and strategies for global learning (pp. 90-106). IGI Global Publishers.

Whatley, M., \& Raby, R. L. (2020). Understanding inclusion in community college education abroad: An investigation of policies and practices. Frontiers, 32(1), 80-103.

Wood, D. (2019). Study abroad outcomes assessment: A community college case study. In G. F. Malveaux \& R. L. Raby (Eds.), Study abroad opportunities for community college students and strategies for global learning (pp. 90-107). IGIGlobal.

Zhang, Y. (2016). An overlooked population in community college: International students' (in)validation experiences with academic advising. Community College Review, 44(2), 153-170. doi:10.1177/0091552116633293

Zhang, Y., \& Hagedorn, L.S. (2013). Chinese education agent views of American community colleges. Community College Journal of Research and Practice 38(8), 721-732. doi:10.1080/10668926.2014.897082.

ROSALIND LATINER RABY, PhD, is a Senior Lecturer in the Educational Leadership and Policy Studies Department at California State University, Northridge. Her major research interests lie in the area of community college international students, community college education abroad, international publishing trends, and higher education research. Email: rabyrl@aol.com 